Jurnal PG-PAUD Trunojoyo: Jurnal Pendidikan dan Pembelajaran Anak Usia Dini, Volume 8, Nomor 1, April 2021 hal 36 - 46, ISSN: 2528-3553 (online), ISSN: 2407-4454 (print)

\title{
PENGARUH PROGRAM PARENTING BERBASIS E- LEARNING TERHADAP LITERASI ORANG TUA TENTANG SUGESTI POSITIF PADA ANAK
}

\author{
Mufarrohah $^{1}$ \\ Siti Fadjryana Fitroh ${ }^{2}$ \\ Dinda Rizki Tiara ${ }^{3}$ \\ ${ }^{1,2,3}$ Program Studi Pendidikan Guru Pendidikan Anak Usia Dini, Universitas Trunojoyo Madura \\ Email:mufarrh00@gmail.com, fadjryana.fitroh@trunojoyo.ac.id,dinda.rtiara@trunojoyo.ac.id \\ Received (Januari), Accepted (Maret), Published (April)
}

\begin{abstract}
The Influence Of E-Learning Based Parenting Programs On Parents Literation On Positive Sugestion In Children. Parental literacy about parenting is very important, especially about positive suggestions. Parents need to give positive suggestions to children so that they can direct them to always behave and have positive habits. However, what happened in the field, especially the parents at KB Muslimat NU Siti Khadijah Bangkalan, still used itsaid do not and rarely give praise to children, this is because parents still do not have good literacy about positive suggestions. This study aims to determine the effect of e-learning-based parenting programs on parental literacy about positive suggestions in children. This study used a quantitative experimental study with a pretest-treatment-posttest design. The subjects of this study were parents at KB Muslimat NU Siti Khadijah Bangkalan. The data collection technique used a questionnaire. Hypothesis testing uses paired t test because the data is normally distributed. The result obtained is a probability value of 0.000. So that the sig value $<0.025$, then Ha is accepted. The data analysis shows that there is a significant influence between the e-learning-based parenting program on parental literacy about positive suggestions in KB Muslimat NU Siti Khadijah Bangkalan. as well as updates on the program parenting based e-learning that is, from a different material side where in this study about positive suggestions in children.
\end{abstract}

Keywords: Literacy, Parenting Program, Positive Suggestion

Abstrak: Pengaruh Program Parenting Berbasis E- Learning terhadap Literasi Orang Tua tentang Sugesti Positif pada Anak. Literasi orang tua tentang pengasuhan sangat penting terutama tentang sugesti positif. Orang tua perlu memberikan sugesti positif kepada anak sehingga dapat mengarahkan anak untuk senantiasa berprilaku dan mempunyai kebiasaan yang positif. Namun, yang terjadi dilapangan khususnya para orang tua di KB Muslimat NU Siti Khadijah Bangkalan masih menggunakan kata jangan atau kalimat larangan dan jarang memberikan pujian kepada anak, hal ini dikarenakan orang tua masih belum memiliki literasi yang baik tentang sugesti positif. Penelitian ini memiliki tujuan untuk mengetahui pengaruh program parenting berbasis e-learning terhadap literasi orang tua tentang sugesti positif pada anak. Penelitian ini menggunakan penelitian kuantitaif eksperimen dengan desain pretest-treatment - posttest. Subjek penelitian ini merupakan orang tua di KB Muslimat NU Siti Khadijah Bangkalan. Teknik pengumpulan data menggunakan angket. Uji hipotesis menggunakan uji t berpasangan karena data berdistribusi normal. Hasil yang diperoleh adalah nilai probabilitas 0,000 . Sehingga nilai sig $<0,025$ maka Ha diterima. Analisis data tersebut menunjukkan terdapat pengaruh yang signifikan antara program parenting berbasis e-learning terhadap literasi orang tua tentang sugesti positif di KB Muslimat NU Siti Khadijah Bangkalan, serta adanya pembaharuan mengenai program parenting berbasis e-learning yakni dari sisi materinya yang berbeda dimana di penelitian ini tentanng sugesti positif pada anak.

Kata Kunci: Literasi, Program Parenting, Sugesti Positif 
Jurnal PG-PAUD Trunojoyo: Jurnal Pendidikan dan Pembelajaran Anak Usia Dini, Volume 8, Nomor 1, April 2021 hal 36 - 46, ISSN: 2528-3553 (online), ISSN: 2407-4454 (print)

\section{PENDAHULUAN}

Pendidikan pada masa kanak-kanak memiliki peran penting, karena perkembangan intelektual, sikap, mental dan kepribadian dibentuk sejak anak masih kecil. Salah satu kebijakan pemerintah disektor pendidikan untuk mendukung pendidikann sepanjang hayat adalah diakuinya pendidikan anak usia dini (PAUD). Pendidikan anak usia dini merupakan upaya pembinaan dalam pemberian rangsangan yang ditujukan untuk anak sejak lahir sampai dengan usia enam tahun dalam membantu perkembangan dan pertumbuhan jasmani, rohani supaya anak memiliki kesiapan dalam memasuki pendidikan lebih lanjut, yang dilaksanakan pada jalur formal, informal, nonformal dan formal (Suyadi, 2013).

Lembaga PAUD jalur non formal yaitu adanya kelompok bermain (KB). Kelompok bermain merupakan lembaga pendidikan untuk anak usia tiga sampai empat tahun sebagai sarana bermain dan belajar bagi anak-anak sebelum memasuki taman kanak-kanak (Isjoni: 2014). Kelompok bermain memiliki tujuan untuk mengembangkan seluruh aspek sosial, mental, emosi dan fisik anak. Lembaga kelompok bermain lebih ditekankan kegiatan bermain dalam memberikan stimulus kepada anak untuk meningkatkan perkembangan dan pertumbuhan anak secara menyeluruh.

Perkembangan merupakan berubahnya batin dan watak yang berlangsung melalui tahapan, dari sederhana sampai yang lebih sulit. Misalnya tingkah laku, kecerdasan, dan sikap. Pertumbuhan adalah bentuk dan ukuran anggota tubuh. Misalnya bertambah tinggi badan, berat badan, bertambah lingkar lengan, dan perubahan tubuh lainnya disebut pertumbuhan fisik (Susanto: 2011). Perkembangan dan pertumbuhan pada anak dipengaruhi oleh faktor genetik dan faktor lingkungan.
Faktor genetik merupakan faktor utama sebagai dasar dalam mencapai tumbuh kembang anak disamping faktor lain. faktor genetik juga mempengaruhi beberapa karakteristik seperti jenis kelamin, ras, rambut, warna mata, pertumbuhan fisik, dan beberapa keunikan. Sedangkan faktor lingkungan ialah yang dipengaruhi dari luar untuk mempengaruhi perkembangan dan pertumbuhan anak, misalnya kebutuhan gizi, pendidikan, pola asuh, dan sebagainya (Festy, 2018). Terdapat tiga jenis lingkungan pendidikan yang paling utama memberikan pengaruh terhadap pengalaman dan kemampuan anak yang biasa disebut Tri pusat pendidikan, antara lain: Pendidikan non-formal (Pendidikan di masyarakat), Pendidikan formal (Pendidikan dalam sekolah), dan yang paling utama pendidikan informal (Pendidikan dalam keluarga) (Triwiyanto, 2015).

Pendidikan keluarga merupakan contoh dari pendidikan informal, keluarga adalah kelompok kecil yang didasarkan ikatan darah dan perkawinan serta rasa tanggung jawab dalam memelihara, merawat dan melindungi anak (Purwanto, 2014). Pendidikan pertama yang diterima oleh anak ialah di dalam keluarga karena dalam keluarga inilah anak pertama-tama mendapatkan didikan dan bimbingan serta anak lebih banyak meluangkan waktu bersama keluarga sehingga anak banyak mencontoh apa yang anak lihat, dengar, dan rasakan. Apapun yang didengar dan dilihat oleh anak akan terekam di dalam otak anak dan tidak bisa hilang. Oleh karena itu, keluarga mempunyai peran sangat penting untuk karakter dan sekesuksesan anak.

Selain keluarga, lembaga KB memegang peran penting dalam pendidikan, karena mempengaruhi pada perkembangan dan pertumbuhan anak, selain keluarga sebagai pusat pendidikan, lembaga KB pun menjadi pusat pendidikan untuk membentuk pribadi anak. Lembaga KB merupakan lembaga pendidikan dan rumah kedua 
Jurnal PG-PAUD Trunojoyo: Jurnal Pendidikan dan Pembelajaran Anak Usia Dini, Volume 8, Nomor 1, April 2021 hal 36 - 46, ISSN: 2528-3553 (online), ISSN: 2407-4454 (print)

setelah keluarga. Lembaga KB dan keluarga memiliki tanggung jawab yang sama dalam memberikan pendidikan yang terbaik untuk anak. Keluarga yang menjadi pendidikan pertama dan lembaga KB yang menjadi pendidikan kedua sudah seharusnya kedua pihak tersebut selalu berkomunikasi untuk senantiasa bersama-sama mendidik anaknya, adanya komunikasi antara guru dan orang tua diharapkan memberikan manfaat bagi tumbuh kembangnya anak.

Orang tua dan lembaga KB memiliki keterkaitan yang kuat satu sama lain. Orang tua dan lembaga $\mathrm{KB}$ sudah seharusnya menjalin kerjasama yang sangat baik antara kedua belah pihak. Orang tua memerlukan layanan dari lembaga KB untuk mendapatkan informasi yang diinginkan mengenai pendidikan anak. Selain itu, lembaga KB membutuhkan partisipasi orang tua untuk meneruskan pendidikan yang sudah didapatkan di lembaga KB untuk diperkuat lagi di rumah serta lembaga KB membutuhkan masukan orang tua dalam menyusun dan melaksanakan programprogram lembaga KB.

Perpaduan pendidikan antara lembaga KB dengan keluarga seharusnya menjadi perhatian bagi para penyelenggara pendidikan, karena layanan pendidikan untuk anak tidak hanya terbatas pada lembaga $\mathrm{KB}$, melainkan juga melibatkan orang tua sebagai pendidik utama di keluarga atau sebagai mitra kerja bagi lembaga. Lembaga perlu mengadakan kegiatan yang melibatkan orang tua dalam kegiatan tersebut salah satunya mengadakan kegiatan program parenting. Program parenting adalah program dukungan dari lembaga yang dikhususkan kepada para orang tua agar semakin memiliki kemampuan dalam hal mengasuh, mendidik, merawat, dan melindungi anaknya di rumah dalam melaksanakan fungsi sosial dan pendidikan, sehingga anak dapat berkembang dan tumbuh secara optimal sesuai dengan usia dan tahap perkembangannya (Kemendiknas, 2011)

Tujuan mengadakan program parenting, yaitu untuk memberikan peningkatan orang tua tentang pengetahuan, sikap dan keterampilan orang tua dalam melakukan peningkatan pengasuhan, pendidikan, perawatan, perlindungan, kesehatan dan gizi anak. Meningkatkan kesadaran orang tua sebagai orang pertama dan utama dalam mendidik anak. Meningkatkan peran orang tua di lembaga maupun dilingkungan masyarakat. Meningkatkan pelaksanaan program lembaga berbasis keluarga (Kemendiknas, 2012). Berdasarkan hal tersebut dapat dikatakan bahwa tujuan dari program parenting adalah untuk meningkatkan keterampilan, sikap dan pengetahuan seputar anak serta untuk meningkatkan kerja sama antara pihak lembaga dan orang tua.

Materi kegiatan program parenting menyesuaikan pada kebutuhan lembaga, terdapat enam materi yang dapat dikembangkan oleh lembaga KB yaitu pendidikan dan perlindungan, pemeliharaan kesehatan, peningkatan gizi, perawatan, dan pengasuhan (Kemendiknas, 2012). Materi pengasuhan yang dapat dikembangkan salah satunya tentang hypnoparenting, mengasuh anak melalui sugesti positif. Sugesti positif merupakan kunci penting untuk menjalin keakraban dengan anak, untuk selalu bersikap akrab, tulus, dan terbuka saat berkomunikasi dengan anak (Lucy, 2012).

Sugesti yang baik adalah sugesti yang melibatkan emosional yang tenang karena akan diterima dipikiran bawah sadar anak sehingga komunikasi dilakukan menjadi efektif. Terdapat beberapa hal yang harus dilakukan orang tua pada saat memberikan sugesti kepada anak yaitu: a) hindari kata jangan kepada anak, apabila orang tua memberikan sugesti negatif kepada anak berisiko tidak dipatuhnya perintah yang diberikan orang tua dan dilanggar oleh anak sehingga jauh dari 
Jurnal PG-PAUD Trunojoyo: Jurnal Pendidikan dan Pembelajaran Anak Usia Dini, Volume 8, Nomor 1, April 2021 hal 36 - 46, ISSN: 2528-3553 (online), ISSN: 2407-4454 (print)

memotivasi anak. Sebaiknya, memberikan sugesti positif kepada anak yang mampu memotivasi anak. b) berikan pujian kepada anak, memberikan pujian kepada anak berdampak positif kepada bawah sadar anak, karena anak akan beranggapan bahwa orang tuanya sangat senang ketika anak melakukan kegiatan hal itu sehingga anak dengan bersemangat dalam mengulanginya lagi.

Berdasarkan observasi pada tanggal 07 November 2019 di KB Muslimat NU Siti Khadijah Bangkalan ketika orang tua terlibat dalam kegiatan kelas anak, masih terdapat orang tua yang mengucapkan kata jangan, "Jangan kesana, jangan ditata seperti itu, jangan lari, jangan bermain tanah" dan pada saat itu anak tidak melakukan perintah yang diberikan oleh orang tua sehingga orang tua berbicara dengan nada yang sedikit keras. Padahal anak usia 1-7 tahun masa emas anak (golden age) tidak bisa mengerti kata jangan, pasti yang dilakukan pikiran bawah sadar mereka adalah melakukan kalimat setelah kata jangan (Syakir, 2014). Selain itu, pada saat kegiatan tersebut orang tua jarang memberikan pujian kepada anaknya ketika anak menemukan puzzle yang diletakkan disekitar pohon dan ketika anak menyelesaikan menata puzzle. Orang tua yang sering menggunakan kata jangan atau banyak larangan kepada anak akan berdampak pada anak, anak semakin membangkang, anak menjadi pasif dan penakut (Syakir, 2014). Orang tua penting untuk mengetahui hal tersebut supaya karakter dalam diri anak terbentuk dengan baik.

Berdasarkan hasil observasi tersebut, penggunaan kata jangan dan jarang memberikan pujian yang dilakukan oleh orang tua kepada anak menunjukkan bahwa pengetahuan orang tua tentang sugesti positif masih kurang. Orang tua yang sering melakukan literasi tidak menggunakan katakata kasar maupun larangan yang akan membuat anak marah. Adapun orang tua yang berliterasi akan membangun karakter anak dengan cara memberikan penjelasan, pengarahan, serta membangun cara pandang anak tentang hal-hal yang belum diketahui, sehingga karakter dalam diri anak akan terbentuk dengan sikap dan pola pikirnya melalui stimulus-stimulus yang diberikan oleh orang tua.

Literasi bukan hanya sekedar kemampuan untuk menulis dan membaca namun untuk menambah keterampilan, pengetahuan, dan kemampuan yang dapat membuat seseorang memiliki kemampuan memecahkan masalah, berkomunikasi secara efektif, mampu berpikir kritis dan mampu berpartisipasi aktif dalam kehidupan masyarakat serta mampu mengembangkan potensi (Alberta dalam Malawi dkk, 2017).

Mengadakan program parenting biasanya dilaksanakan secara tatap muka antara peserta dan pemateri. Namun, pada penelitian ini program parenting dilaksanakan berbasis e-learning karena pada saat peneliti melakukan penelitian, Indonesia sedang dilanda wabah virus corona, untuk memutuskan rantai penyebaran virus covid-19 dilakukan upaya oleh pemerintah dalam mengurangi adaptasi.

Program parenting berbasis $e$ learning adalah cabang dari pendidikan orang dewasa yang diselenggarakan melalui tahap perencanaan yang melibatkan orang tua sebagai peserta, pelaksanaan yang dilakukan dalam durasi waktu tertentu dengan pilihan materi yang telah disepakati bersama, dan evaluasi kegiatan yang dilaksanakan untuk mengukur hasil program parenting berbasis $e$ - learning (Saepudin \& Ulfah, 2014). Program parenting berbasis $e$ learning yang diselenggarakan untuk orang tua dengan memanfaatkan perangkat elektronik khususnya pada handphone dan internet.

Membaca pemaparan di atas, permasalahan berkaitan dengan minimnya literasi orang tua tentang sugesti positif pada anak. sehingga tujuan dari penelitian ini lebih difokuskan pada pengaruh program 
Jurnal PG-PAUD Trunojoyo: Jurnal Pendidikan dan Pembelajaran Anak Usia Dini, Volume 8, Nomor 1, April 2021 hal 36 - 46, ISSN: 2528-3553 (online), ISSN: 2407-4454 (print)

parenting berbasis e-learning terhadap literasi orang tua tentang sugesti positif pada anak.

\section{METODE}

Penelitian dilakukan menggunakan pendekatan penelitian kuantitatif dengan menggunakan metode eksperimen. Metode penelitian eksperimen adalah metode penelitian yang dilakukan untuk mencari pengaruh perlakuan tertentu terhadap yang lain dalam kondisi yang terkendalikan (Sugiyono, 2014). Metode eksperimen dalam penelitian ini adalah desain one group pretest-postest. Rancangan desain penelitian one group pretest-postest adalah sebagai berikut:

\begin{tabular}{|l|l|l|l|}
\hline Kelompok & pretest & Treatment & Postest \\
\hline Eksperimen & $\mathrm{Q} 1$ & $\mathrm{X}$ & $\mathrm{Q} 2$ \\
\hline
\end{tabular}

Keterangan:

$\mathrm{Q}_{1}$ : Literasi orang tua tentang sugesti positif pada anak sebelum diberi perlakuan.

$\mathrm{X}$ : Perlakuan yang diberikan dengan melaksanakan program parenting berbasis $e$ learning

. $\mathrm{Q}_{2}$ : Literasi orang tua tentang sugesti positif pada anak setelah diberi perlakuan.

Tempat penelitian dilakukan di KB Muslimat NU Siti Khadijah Bangkalan. Waktu penelitian dimulai pada bulan November tahun 2019 digunakan sebagai studi pendahuluan, dan dilanjutkan lagi pada bulan Juli tahun 2020 digunakan untuk pengambilan data dan pengelolaan data. sampel yang digunakan dalam penelitian ini menggunakan jenis sampling jenuh. Sampling jenuh yaitu semua anggota populasi digunakan sebagai sampel dalam teknik penentuan sampel (Sugiyono, 2014). Penelitian ini menggunakan sampel jenuh, karena jumlah populasi relative kecil kurang dari 30 responden. Sampel yang digunakan sebanyak $11 \mathrm{ibu}$ di KB Muslimat NU Siti
Khadijah Bangkalan yang mengikuti program parenting berbasis $e$-learning.

Pengumpulan data menggunakan angket yang diberikan kepada orang tua secara daring dengan mengisi google form sebelum dan sesudah pelaksanaan program parenting berbasis e-learning. Angket ini digunakan untuk menggali data tentang literasi orang tua tentang sugesti positif pada anak. Penggunaan kuesioner dalam penelitian ini adalah menggunakan pernyataan tertutup karena pilihan jawaban telah disediakan, kemudian responden hanya menjawab pernyataan sesuai dengan pendapat responden. Angket terdiri dari 16 item pernyataan dengan 8 item pernyataan favorable dan 8 item pernyataan unfavorable yang menggunakan skala likert dengan empat alternatif jawaban.

Dalam analisis data peneliti menggunakan uji normalitas dan uji hipotesis menggunakan SPSS. 25. Uji normalitas digunakan untuk menentukan distribusi data dan menentukan teknik statistik yang akan digunakan pada tahap selanjutnya. Peneliti menggunakan uji One Kolmogorov-Smirnov Test karena data yang akan di uji merupakan data tunggal dengan level signifikansi $(\alpha) 5 \%$ atau 0.05 . Uji hipotesis menggunakan uji parametrik berupa uji $\mathrm{t}$ berpasangan (Paired Sample Test) yang bertujuan untuk melihat perbedaan literasi orang tua tentang sugesti positif pada anak sebelum dan sesudah mengikuti kegiatan program parenting berbasis e-learning.

\section{HASIL DAN PEMBAHASAN \\ Hasil}

Penelitian ini meneliti pengaruh program parenting berbasis e-learning terhadap literasi orang tua tentang sugesti positif pada anak. Angket diberikan selama dua kali, sebelum dan sesudah wali murid mengikuti kegiatan program parenting berbasis $e$ learning. Hasil dari pretest dan posttest tersajikan dalam tabel 1. 
Jurnal PG-PAUD Trunojoyo: Jurnal Pendidikan dan Pembelajaran Anak Usia Dini, Volume 8, Nomor 1, April 2021 hal 36 - 46, ISSN: 2528-3553 (online), ISSN: 2407-4454 (print)

Tabel 1. Hasil Uji Normalitas Menggunakan Spss For Windows

\begin{tabular}{|c|c|c|c|c|}
\hline \multirow{2}{*}{$\begin{array}{c}\text { Literasi } \\
\text { orang }\end{array}$} & \multirow{2}{*}{ Tes } & \multicolumn{3}{|c|}{ Shapiro-Wilk } \\
\cline { 2 - 5 } tua & Pretest & 0,939 & 11 & 0,510 \\
\cline { 2 - 5 } & Posttest & 0,854 & 11 & 0,049 \\
\hline
\end{tabular}

Berdasarkan tabel 1. diketahui bahwa data berdistribusi normal. Hal tersebut dibuktikan dengan nilai signifikansi lebih dari 0,05 yakni 0,510 untuk signifikansi kode nilai pretest dan 0,049 untuk signifikansi kode nilai posttest. Dari hasil uji normalitas tersebut bahwa data berdistribusi normal maka untuk uji hipotesisnya dapat menggunakan uji parametrik berupa uji $\mathrm{t}$ berpasangan (Paired Sample Test), uji ini digunakan untuk mengetahui ada tidaknya pengaruh nilai rata-rata antara dua kelompok data yang berpasangan. Berpasangan disini maksudnya adalah satu sampel mendapat perlakuan berbeda dari dimensi waktu.

Tabel 2. Hasil Uji T Berpasangan

\begin{tabular}{|c|c|c|c|c|c|c|c|c|}
\hline & \multicolumn{5}{|c|}{ Paired Difference } & \multirow{3}{*}{$\mathrm{T}$} & \multirow{3}{*}{$\mathrm{df}$} & \multirow{3}{*}{$\begin{array}{l}\text { Sig } \\
.(2 \\
- \\
\text { tail } \\
\text { ed) }\end{array}$} \\
\hline & \multirow[t]{2}{*}{$\begin{array}{l}\mathrm{Me} \\
\text { an }\end{array}$} & \multirow[t]{2}{*}{$\begin{array}{c}\text { Std. } \\
\text { Dev } \\
\text { iati } \\
\text { on }\end{array}$} & \multirow[t]{2}{*}{$\begin{array}{c}\text { Std } \\
\text { Eror } \\
\text { Mea } \\
\text { n }\end{array}$} & \multicolumn{2}{|c|}{$\begin{array}{c}95 \% \\
\text { Confidenc } \\
\text { e Interval } \\
\text { Of The } \\
\text { Different }\end{array}$} & & & \\
\hline & & & & $\begin{array}{c}\text { Lo } \\
\text { wer }\end{array}$ & $\begin{array}{l}\text { Up } \\
\text { per }\end{array}$ & & & \\
\hline $\begin{array}{l}\text { Pret } \\
\text { est- } \\
\text { post } \\
\text { est }\end{array}$ & $\begin{array}{c}- \\
20, \\
818\end{array}$ & $\begin{array}{l}5,2 \\
88\end{array}$ & $\begin{array}{c}1,59 \\
4\end{array}$ & $\begin{array}{c}- \\
24, \\
371\end{array}$ & $\begin{array}{c}- \\
17, \\
266\end{array}$ & $\begin{array}{c}- \\
13 \\
, 0 \\
57\end{array}$ & 10 & $\begin{array}{c}0,0 \\
00\end{array}$ \\
\hline
\end{tabular}

Berdasarkan tabel 2. menunjukkan bahwa nilai signifikansi yang diperoleh sebesar 0,000. Berdasarkan hasil pengujian nilai taraf signifikan $0,05 / 2=0,025$ dan nilai probabilitas 0,000. Sesuai dengan kriteria pengujian hipotesis sebelumnya yang menyatakan jika sig >0,05/2 maka Ho diterima. Berdasarkan hasil kriteria uji $t$ berpasangan diperoleh hasil bahwa $0,000<$ 0,025 maka dapat dikatakan Ho ditolak dan Ha diterima, sehingga dapat diartikan bahwa ada pengaruh program perenting berbasis $e$ learning terhadap literasi orang tua tentang sugesti positif pada anak. Hal ini berarti bahwa kegiatan program parenting berbasis e-learning dapat mempengaruhi literasi orang tua tentang sugesti positif pada anak.

\section{Pembahasan}

Penelitian ini meneliti literasi orang tua tentang sugesti positif pada anak. Penelitian dilaksanakan dalam 3 tahap diantaranya tahap sebelum perlakuan (pretest), tahap pemberian perlakuan (treatment) dan tahap sesudah pemberian perlakuan (posttest). Pada tahap pretest dan posttest kegiatan yang dilakukan oleh peneliti ialah pengambilan data menggunakan angket yang dilakuan secara online dengan memberikan link google form pada orang tua untuk mengisi angket sebelum dan sesudah diberikan perlakuan. Pada kegiatan treatment peneliti melaksanakan kegiatan program parenting.

Berdasarkan data yang diperoleh melalui penyebaran angket hasil perhitungan uji hipotesis jika sig > 0,05/2 maka Ho diterima. Hasil kriteria uji $t$ berpasangan diperoleh hasil $0,000<0,025$ maka dapat dikatakan Ho ditolak dan Ha diterima, sehingga dapat diartikan bahwa ada pengaruh yang signifikan literasi orang tua sebelum dan sesudah mengikuti program parenting berbasis e-learning. Hal ini berarti bahwa kegiatan program parenting berbasis $e$ learning dapat mempengaruhi literasi orang tua tentang sugesti positif pada anak. Kenaikan literasi orang tua tentang sugesti positif pada anak setelah mengikuti program parenting berbasis e-learning sejalan dengan penelitian yang telah dilakukan oleh Siti Fadjryana Fitroh \& Eka Oktavianingsih (2020) bahwa kegiatan parenting education dinyatakan efektif dalam meningkatkan literasi kesehatan ibu dalam pencegahan stunting.

Pelaksanaan treatment berupa kegiatan program parenting berbasis $e$ - 
Jurnal PG-PAUD Trunojoyo: Jurnal Pendidikan dan Pembelajaran Anak Usia Dini, Volume 8, Nomor 1, April 2021 hal 36 - 46, ISSN: 2528-3553 (online), ISSN: 2407-4454 (print)

learning. Program parenting adalah program dukungan dari lembaga yang dikhususkan kepada orang tua agar semakin memiliki kemampuan dalam hal mengasuh, mendidik, merawat dan melindungi anaknya di rumah dalam melaksanakan fungsi sosial dan pendidikan, sehingga anak dapat berkembang dan tumbuh secara optimal sesuai dengan usia dan tahap perkembangannya (Kemendiknas, 2011). Elearning merupakan pembelajaran formal dan informal dengan menggunakan media elektronik seperti internet, intranet, handphone, CD-ROM, Video tape, DVD, TV dan sebagainya (Linde dalam Simanihuruk dkk, 2019).

Kegiatan program parenting berbasis $e$ learning yang diselenggarakan untuk orang tua dengan memanfaatkan perangkat elektronik khususnya pada handphone dan internet dengan menggunakan aplikasi whatsapp yang difasilitasi suara, video, tampilan slide show materi, musik media player, dan kolom chat. Selain itu program parenting berbasis e-learning dalam penelitian ini memberikan informasi kepada orang tua seputar sugesti positif.

Sugesti positif adalah kunci penting untuk menjalin keakraban bersama anak, dengan memberikan sugesti positif orang tua dapat selalu bersikap tulus, akrab, dan terbuka saat berkomunikasi dengan anak (Lucy, 2012). Terdapat beberapa syarat yang harus diperhatikan ketika memberikan sugesti positif kepada anak, yaitu hindari kata "jangan" kepada anak dan memberikan pujian (Syakir, 2014).

Hasil angket sebelum dan sesudah pemberian perlakuan memiliki hasil yang berbeda, karena pada saat sebelum diberikan treatment orang tua belum mendapatkan informasi tentang sugesti positif hindari kata "jangan" dan memberikan pujian. Sebelum diberikan perlakuan jumlah hasil angket rata-rata mendapatkan nilai 2,13 dengan kriteria sedang. Sedangkan, pada saat sesudah diberikan perlakuan jumlah hasil angket rata-rata mendapatkan nilai 3,44 dengan kriteria sangat tinggi. Adanya sebuah perubahan pada hasil angket literasi orang tua tentang sugesti positif karena orang tua sudah diberikan treament berupa kegiatan program parenting berbasis e-learning. Hal ini senada dengan penelitian yang telah dilaksanakan oleh Child Welfare Information Gateway (2019) bahwa melalui program parenting dapat meningkatkan pengetahuan dan praktik pengasuhan orang tua dalam kemampuan berkomunikasi yang positif pada anak serta mengetahui waktu yang tepat menggunakan emosi dan perilaku yang baik kepada anak.

Pada saat pelaksanaan pretest, kegiatan pengambilan data berupa angket literasi orang tua tentang sugesti positif mendapatkan kriteria sedang. Hal tersebut dikarenakan pada saat orang tua mengisi angket rata-rata orang tua mendapkan skor 2 pada pernyataan favorable dan unfavorable literasi orang tua tentang sugesti positif. Setelah pelaksanaan pretest dilanjutkan dengan pelaksanaan treatment berupa kegiatan program parenting.

Program parenting dilaksanakan berbasis e-learning dikarenakan pada saat peneliti melakukan penelitian indonseia bahkan seluruh dunia sedang dilanda virus corona, untuk memutus rantai penyebaran virus corona maka program parenting dilaksanakan berbasis e-learning. Pelaksanaan program parenting berbasis $e$ learning dipandu oleh moderator untuk kelancaran acara. Pada saat pelaksanaan program parenting berbasis e-learning, pengaturan group WA diatur menjadi hanya admin yang dapat mengirim pesan, hal tersebut diatur untuk ke efektifan pada saat acara, setelah penyampaian materi selesai pengaturan group diubah menjadi mengizinkan agar semua peserta dapat mengirim pesan ke group. Setelah selesai memberikan informasi kepada orang tua dilanjutkan dengan sesi tanya jawab antara pemateri dan orang tua. 
Jurnal PG-PAUD Trunojoyo: Jurnal Pendidikan dan Pembelajaran Anak Usia Dini, Volume 8, Nomor 1, April 2021 hal 36 - 46, ISSN: 2528-3553 (online), ISSN: 2407-4454 (print)

Informasi yang diberikan kepada orang tua dalam kegiatan program parenting berbasis e-learning yaitu tentang sugesti positif yang dipaparkan langsung oleh penulis buku hypnoparenting yang menjadi rujukan dalam penelitian ini. Materi tentang sugesti positif disesuaikan dengan kebutuhan lembaga atau orang tua. Hal ini senada dengan Kementrian Pendidikan Nasional bahwa pengembangan materi program parenting disesuaikan dengan kebutuhan setiap lembaga karena lembaga lebih mengetahui kondisi di lapangan tentang informasi yang paling dibutuhkan oleh para orang tua dalam mengasuh, membimbing dan mendidik anak-anaknya (Kemendiknas, 2012). Apabila informasi yang disampaikan sesuai dengan kebutuhan orang tua maka informasi yang disampaikan mudah diterima dengan baik oleh para orang tua dan dapat merubah pola asuh orang tua sesuai dengan karakter dan perkembangan anak. Secara garis besar terdapat enam bahasan materi yang dapat dikembangkan oleh lembaga $\mathrm{KB}$ yakni peningkatan gizi, pemeliharaan kesehatan, perawatan, pengasuhan, Pendidikan dan perlindungan (Kemendiknas, 2012). Pada saat program parenting berbasis e-learning materi sesuai dengan kebutuhan lembaga atau orang tua yaitu minimnya literasi orang tua tentang sugesti positif pada anak.

Penyampaian materi oleh pemateri disesuaikan dengan penelitian peneliti, yaitu tentang aspek-aspek literasi orang tua tentang sugesti positif. Aspek yang pertama tentang aspek meyimak tentang sugesti positif yang meliputi indikator menyimak tentang hindari kata jangan dan indikator menyimak tentang memberikan pujian. Pada saat acara pemateri menyampaikan materi tentang hindari kata jangan dan memberikan pujian pada anak. Sehingga saat pemateri menyampaikan materi, orang tua mendengarkan voice note yang diberikan oleh pemateri tentang hindari kata jangan atau menggunakan kalimat positif dan memberikan pujian. Hal ini senada dengan Tarigan dalam Ahmadi \& Ibda (2017) bahwa menyimak adalah mendengarkan (memperhatikan) baik-baik yang diucapkan orang.

Aspek yang kedua tentang aspek membaca tentang sugesti positif yang meliputi indikator membaca tentang hindari kata jangan dan indikator membaca tentang memberikan pujian. Pada saat program parenting berbasis e-learning pemateri menulis materi tentang, pentingnya orang tua menggunakan kalimat positif karena membuat mental anak semakin kuat, pantang menyerah dan kepercayaan diri semakin tinggi dan pemateri juga menulis tentang orang tua memberikan pujian pada anak. Sehingga apa yang ditulis oleh pemateri dapat dibaca oleh orang tua. Hal ini sesuai dengan Tarigan dalam Ahmadi \& Ibda (2017) bahwa membaca adalah melihat serta memahami isi dari apa yang tertulis, mengeja atau melafalkan apa yang tertulis.

Aspek yang ketiga tentang aspek berbicara tentang sugesti positif yang meliputi indikator berbicara tentang hindari kata jangan dan indikator berbicara tentang memberikan pujian. Pada saat acara program parenting berbasis e-learning pemateri memberikan contoh berbicara kepada anak menggunakan kalimat positif dan memberikan contoh cara berbicara kepada anak memberikan pujian yang baik. Pemateri memberikan contoh cara berbicara orang tua kepada anak bertujuan untuk dapat diterapkan oleh orang tua saat berbicara dengan anak menggunakan kalimat positif dan orang tua dapat menerapkan cara memberikan pujian yang baik pada anak. Hal ini sesuai dengan Tarigan dalam Ahmadi \& Ibda (2017) bahwa berbicara ialah bentuk komunikasi dengan menggunakan media bahasa, berbicara merupakan proses penuangan gagasan dalam bentuk ujuran-ujaran.

Aspek yang ke empat tentang aspek menulis tentang sugesti positif yang meliputi 
Jurnal PG-PAUD Trunojoyo: Jurnal Pendidikan dan Pembelajaran Anak Usia Dini, Volume 8, Nomor 1, April 2021 hal 36 - 46, ISSN: 2528-3553 (online), ISSN: 2407-4454 (print)

indikator menulis tentang hindari kata jangan dan indikator menulis tentang memberikan pujian. Pada saat pelaksanaan program parenting berbasis e-learning pemateri memberikan materi tentang hindari kata jangan dan memberikan pujian. Pemateri memberikan materi tersebut diharapkan orang tua menulis materi tentang sugesti positif untuk keperluannya dalam mengasuh anak. Hal ini sesuai dengan Tarigan dalam Ahmadi \& Ibda (2017) bahwa menulis merupakan pengungkapan yang di implementasikan melalui huruf atau angka (tulisan). Orang tua dapat menulis informasi yang diperoleh dalam pelaksanaan program parenting berbasis e-learning untuk keperluan dalam mengasuh anak, informasi yang didapatkan pada saat program parenting berbasis e-learning ialah seputar sugesti positif tentang hindari kata jangan dan memberikan pujian.

Setelah pelaksanaan program parenting berbasis e-learning, dilanjutkan dengan kegiatan posttest dengan pengambilan data menggunakan angket. Pengambilan angket dilaksanakan secara online dengan mengirim link google form yang dikirim melalui Whatshaap. Angket posttest sama halnya dengan angket pretest literasi orang tua tentang sugesti positif. Hasil angket literasi orang tua tentang sugesti positif setelah diberikan perlakuan mendapatkan kriteria yang sangat tinggi. Hal tersebut dikarenakan pada saat orang tua mengisi angket rata-rata orang tua mendapatkan skor 4 pada pernyataan favorable dan unfavorable literasi orang tua tentang sugesti positif.

Literasi orang tua tentang sugesti positif pada anak di KB Muslimat NU Siti Khadijah Bangkalan, pada saat pretest aspek menyimak informasi tentang sugesti positif rata-rata orang tua mendapatkan nilai 2 Setelah mengikuti kegiatan program parenting berbasis e-learning dengan materi sugesti positif pada aspek menyimak informasi tentang sugesti positif rata-rata orang tua mendapatkan nilai 4 . Terdapatnya perubahan pada aspek menyimak informasi tentang sugesti positif karena orang tua sudah menyimak informasi tentang sugesti positif, orang tua sudah faham apa yang disampaikan pemateri pada saat kegiatan program parenting berbasis e-learning, dan orang tua sudah faham pentingnya menggunakan sugesti positif pada anak. Hal ini diperkuat oleh Andika Aldi Setiawan (2019) bahwa menyimak adalah keterampilan berbahasa yang bersifat menerima dengan penuh pemahaman dan perhatian untuk mendapatkan informasi yang diucapkan oleh pembicara melalui lisan. Menyimak informasi dengan penuh pemahaman membuat orang tua faham informasi yang disampaikan oleh pemateri.

Pada saat pretest aspek membaca tentang sugesti positif rata-rata orang tua mendapatkan nilai 2 Setelah mengikuti kegiatan program parenting berbasis $e$ learning dengan materi sugesti positif pada aspek membaca informasi tentang sugesti positif rata-rata orang tua mendapatkan nilai 4. Terdapatnya perubahan pada aspek membaca tentang sugesti positif, orang tua sudah membaca tentang sugesti positif dan orang tua sudah membaca pentingnya orang tua menggunakan kalimat sugesti positif pada anak. Hal ini diperkuat oleh Andika Aldi Setiawan (2019) bahwa membaca adalah proses penerjemahan simbol untuk mendapatkan informasi yang disampaikan penulis melalui tulisan. Melalui kegiatan membaca tentang sugesti positif, orang tua mendapatkan informasi seputar sugesti positif yang telah ditulis oleh pemateri pada saat kegiatan program parenting berbasis $e$ learning.

Pada saat pretest aspek berbicara tentang sugesti positif rata-rata orang tua mendapatkan nilai 2 Setelah mengikuti kegiatan program parenting berbasis $e$ learning dengan materi sugesti positif pada aspek berbicara tentang sugesti positif ratarata orang tua mendapatkan nilai 4 . Terdapatnya perubahan pada aspek berbicara 
Jurnal PG-PAUD Trunojoyo: Jurnal Pendidikan dan Pembelajaran Anak Usia Dini, Volume 8, Nomor 1, April 2021 hal 36 - 46, ISSN: 2528-3553 (online), ISSN: 2407-4454 (print)

tentang sugesti positif, orang tua sudah mendapatkan contoh cara berbicara menggunakan sugesti positif pada saat kegiatan program parenting berbasis $e$ learning. Hal ini diperkuat oleh Andika Aldi Setiawan (2019) bawa berbicara adalah keterampilan untuk menyampaikan keinginan, kebutuhan perasaan dan kehendak kepada orang lain.

Pada saat pretest aspek menulis tentang sugesti positif rata-rata orang tua mendapatkan nilai 2 Setelah mengikuti kegiatan program parenting berbasis $e$ learning dengan materi sugesti positif pada aspek menulis tentang sugesti positif ratarata orang tua mendapatkan nilai 4 . Terdapatnya perubahan pada aspek menulis tentang sugesti positif, orang tua menulis materi yang sudah diberikan oleh pemateri untuk keperluan dalam mengasuh anak. Hal ini diperkuat oleh Andika Aldi Setiawan (2019) bahwa menulis adalah keterampilan berbahasa melalui sebuah tulisan yang digunakan untuk mencatat keperluan sendiri dan untuk berkomunikasi secara tidak langsung. Orang tua menulis informasi yang sudah diterima pada saat kegiatan program parenting berbasis e-learning.

Literasi orang tua tentang sugesti positif di KB Muslimat NU Siti Khadijah Bangkalan, secara keseluruhan saat pretest mendapatkan kriteria sedang literasi orang tua tentang sugesti positif. Setelah mengikuti kegiatan program parenting berbasis $e$ learning dengan materi sugesti positif, membuat literasi orang tua menjadi meningkat dengan mendapatkan kriteria sangat tinggi literasi orang tua tentang sugesti positif. Hal ini sesuai dengan tujuan program parenting berbasis e-learning yaitu untuk meningkatkan kesadaran orang tua sebagai pendidik yang pertama dan utama, meningkatkan pengetahuan, sikap dan keterampilan orang tua dalam melakukan peningkatan pengasuhan, pendidikan dan perlindungan anak (Kemendiknas, 2012). Mengikuti kegiatan program parenting menjadikan cara pengasuhan orang tua menjadi lebih baik dari sebelumnya dan menambah pengetahuan orang tua seputar pengasuhan anak yang benar sesuai dengan tahapan pertumbuhan dan perkembangan anak.

\section{SIMPULAN}

Hasil penelitian dan hasil pembahasan dapat disimpulkan bahwa terdapat pengaruh yang signifikan antara program parenting berbasis e-learning terhadap literasi orang tua tentang sugesti positif pada anak di KB Muslimat NU Siti Khadijah Bangkalan. Hal tersebut terbukti dari hasil uji parametrik berupa uji $\mathrm{t}$ berpasangan (Paired Sample Test), diperoleh hasil $0,000<0,025$ maka dapat dikatakan Ho ditolak dan Ha diterima. Sehingga dapat diartikan bahwa ada pengaruh program parenting berbasis e-learning terhadap literasi orang tua tentang sugesti positif pada anak.

\section{SARAN}

Berdasarkan dari hasil penelitian yang telah dilakukan oleh peneliti dan telah dipaparkan maka dapat disimpulkan beberapa saran yang dapat diberikan, antara lain: (1) orang tua hendaknya mendukung dan aktif disetiap kegiatan program parenting, mengingat pentingnya kerjasama antara lembaga dan orang tua, serta orang tua setelah mendapatkan materi program parenting diharapkan untuk menerapkan hasil yang di dapatkan kepada anak untuk memperbaiki kualitas pengasuhan. (2) pada saat melaksanakan program parenting berbasis $e$ learning bisa dilaksanakan menggunakan konsep virtual classroom (vc) karena berkaitan dengan kehadirannya orang tua pada saat pelaksanaan program parenting berbasis $e$ - learning. 
Jurnal PG-PAUD Trunojoyo: Jurnal Pendidikan dan Pembelajaran Anak Usia Dini, Volume 8, Nomor 1, April 2021 hal 36 - 46, ISSN: 2528-3553 (online), ISSN: 2407-4454 (print)

\section{DAFTAR PUSTAKA}

Ahmadi, Farid dan Ibda, Hamidulloh. (2017). Media Literasi Sekolah (Teori dan Praktik) Jawa Tengah: Pilar Nusantara.

Child Welfare Information Gateway. (2019). Parent Education to Strengthen Families and Reduce the Risk of Maltreatment. Washington. DC: U.S Departement of Health and Human Services. Children's Bureau.

Festy, Pipit. (2018). Buku Ajar Gizi dan Diet. Surabaya: UMSurabaya Publishing.

Fitroh, SF. \& Oktavianingsih, E. (2020). Peran Parenting Dalam Meningkatkan Literasi Kesehatan Ibu Terhadap Stunting di Bangkalan Madura. Jurnal Obsesi: Jurnal Pendidikan Anak Usia Dini. Vol. 4 No. 2.

Isjoni. (2014). Model Pembelajaran Anak Usia Dini. Bandung: Alfabeta.

Kementrian Pendidikan Nasional. (2011). Petunjuk Teknis Orientasi Teknis Peningkatan Pemahaman Program Penguatan PAUD Berbasis Keluarga (Parenting). Jakarta: Kemendiknas

Kementrian Pendidikan Nasional. (2012). Pedoman Penyelenggaraan Pendidikan Anak Usia Dini Berbasis Keluarga, Direktorat Pembinaan Pendidikan Anak Usia Dini, Nonformal, dan Informal. Jakarta: Direktur Pembinaan PAUD

Lucy, B., (2012). 5 Menit Menguasai Hypnoparenting. Jakarta: Swadaya Group.
Purwanto, Nanang. (2014). Pengantar Pendidikan. Yogyakarta: Graha Ilmu. Saepudin, Asep \& Ulfah, Saly. (2020). Penerapan Program Parenting Berbasis E-Learning Dalam Mengembangkan Kemampuan Mendidik Anak (Studi Pada Anggota Komunitas Institut Ibu Profesional di Bandung). 2014. Vol. 18 No. 3. hlm. 249. Diakses online: 15 September 2020 pukul 11.17 WIB.

Setiawan, A, A. (2019). Penguatan Literasi Siswa Sekolah Dasar: Prosiding Seminar Nasional Peran Pendidikan Dasar Dalam Menyiapkan Generasi Unggul Di Era Revolusi Industri 4.0. Yogyakarta:

Universitas Sarjanawiyata Tamansiswa.

Simanihuruk, Lidia dkk. (2019). E-learning: Implementasi, Strategi dan Inovasinya. Medan: Yayasan Kita Menulis

Sugiyono. (2014). Metode Penelitian Kuantitatif Kualitatif dan $R \& D$. Bandung: Alfabeta.

Susanto, Ahmad. (2011). Perkembangan Anak Usia Dini: Pengantar Dalam Berbagai Aspeknya. Jakarta: Prenadamedia Group.

Suyadi. (2013). Teori Pembelajaran Anak Usia Dini. Bandung: Remaja Rosdakarya

Syakir,S., E., (2014). Islamic Hypnoparenting: Mendidik Anak Masa Kini Ala Rasulullah. Jakarta: Kawan Pustaka.

Triwiyanto, Teguh. (2015). Pengantar Pendidikan. Jakarta: Bumi Aksara 